\title{
Some Reflections on Graduate Professional Education in Adult Education
}

\author{
COOLIE VERNER*
}

\begin{abstract}
Adult education is a relatively new discipline that is appearing with greater frequency in university curriculae. Although Columbia University established the first department in 1930 proliferation has been slow and by 1962 some fifteen universities had established departments ${ }^{1}$. Among these, were some of the most noted universities on the continent. Well over 100 universities and colleges now purport to offer graduate professional education in adult education but it is doubtful that all of these are in fact legitimate programs in adult education.

With the growth in the number of university programs has come a corresponding increase in the number of professionally educated people supplied to the field. At the same time, these programs have accelerated the development of knowledge about educating adults. By 1973, there had been awarded some 1,393 doctorates in adult education ${ }^{2}$ and the number of research studies has increased $a$ hundredfold with an accelerating annual rate of increase ${ }^{3}$.

This growth in university programs of graduate professional education reflects an increasing recognition of adult education as a field of social practice and as an academic discipline ${ }^{4}$. The growth in programs has not been entirely logical or constructive as it has tended to occur solely within Schools of Education where it has been viewed primarily as an extension of pedagogy rather than as a distinct subject with its own unique body of knowledge and practice. Furthermore, this has tended to divisiveness as it has excluded major components of adult education such as agricultural extension or public health education.

Too many of the newer university programs are in the hands of individuals not expert in the discipline with the result that graduates are released to the field deficient in knowledge and without a clear perception of the unique characteristics of the profession they have entered. This results in practice that is little more than an extension of schooling rather than in carefully structured learning opportunities for adults.

In part, the cause of this perversion of the discipline can be found in the too rapid
\end{abstract}

*Professor of Adult Education, The University of British Columbia. 
proliferation of programs and in the inability of the older established universities to supply the academic cadre required to staff new programs; but for the most part it is due to the failure of deans and faculties of education to recognize and accept adult education as an academic discipline with its own distinctive body of knowledge related to but different from the normal concerns of a school of education. As a result, personnel to staff programs are drawn from education rather than adult education or they may be experienced practitioners drawn from the field on the assumption that experience is more relevant than knowledge.

This inability to accept adult education as a distinct field and discipline stems from a too limited perception of the phenomenon called education. Since schools of education are principally concerned with the preparation of professional leadership for and the advancement of knowledge about the traditional educational institutions in society, education is equated with schooling and learning with education.

Adult education operates both within and apart from the traditional institutionalized forms of education, consequently it is concerned with learning events in a wider social milieu and this produces a broader conception of education than that of schooling and it begins from a different base. Thus, adult education deals with education in many diverse ways that are unrecognizable to those whose perception of education is limited to institutionalized forms. As a result, adult education must deal with terms and concepts borrowed from pedagogy but reformulated to fit the kinds of phenomena encountered in educating adults ${ }^{5}$. Professional education for adult education must of necessity be broader in scope and intrinsically different from that provided for leadership for the established educational institutions.

\section{RESUME}

La formation des adultes, discipline relativement nouvelle, parait de plus en plus fréquemment dans le cadre des programmes universitaires. Bien que l'Universite Columbia en ait établi, en 1930, le premier département, la prolifération de ce genre de programme se fait lentement. En 1962, une quinzaine d'universités avaient mis sur pied des départements de formations des adultes. Parmi ces institutions, se rangent un certain nombre des universités les plus célèbres en Amérique du Nord. Bien plus de 100 universités et collèges prétendent, à l'heure actuelle, offrir, dans le cadre de leurs programmes d'enseignement supérieur, des cours de ce genre. Il est toutefois douteux que tous ces cours s'avèrent des contributions légitimes à cette discipline.

Le nombre croissant de programmes universitaires va de pair avec celui de personnes formées pour se charger de l'avenir de la discipline. En même temps, ces programmes ont accéléré le développement des connaissances en ce qui concerne la formation des adultes. Dès 1973, les universités avaient décerné quelques 1,393 doctorats aux étudiants spécialisés dans ce domaine et le nombre de travaux de recherches avait augmenté de 100 fois, avec un nombre plus important de travaux chaque année. 
Cette croissance des programmes universitaires sur l'enseignement supérieur professionnel, reflète une reconnaissance accrue de la formation des adultes en tant que domaine d'effort social et discipline académique.

Le développement de ces programmes n'a pas été entièrement logique ni constructif. C'est-à-dire, cette discipline a tendance à s'élaborer au sein d'une faculté de pédagogie où elle est traitée principalement comme une extension de la pédagogie et non pas comme une matière distincte qui possède sa propre et unique accumulation de connaissances et de pratiques. D'ailleurs, cette situation a encouragé les divisions. Certains composants majeurs d'un programme de formation des adultes se trouvent exclus des programmes établis. (ex. les cours avec leur application en agriculture et les programmes de santé publique.)

Un corps enseignant qui n'est pas spécialisé dans la discipline se charge trop souvent de programmes universitaires plus récents. Il en résulte que les diplômés possèdent des connaissances incomplètes de leur discipline et une perception peu claire des caractéristiques spéciales de la carrière pour laquelle ils ont opté. Ca fait qu'en pratique, les cours d'adultes n'offrent qu'un prolongement des années scolaires et non pas un stage de formation pour adultes soigneusement structuré.

La prolifération trop rapide de ces programmes et l'impuissance de la part des vieilles universités établies de fournir le personnel académique requis pour se charger de ces nouveaux programmes expliquent, en partie, la perversion de cette discipline. Toutefois, en grande partie, il s'agit d'un échec de la part des doyens et des facultés de pédagogie qui n'ont ni reconnu ni accepté la formation des adultes en tant que discipiine académique ayant sa propre accumulation distincte de connaissances. Par conséquent, pour trouver le personnel enseignant qui se chargent de ces programmes, les universités font appel aux spécialistes en pédagogie et non pas en formation des adultes.

Elles font appel également aux praticiens expérimentés d'une discipline sur l'hypothèse que l'expérience s'avère plus pertinente que les connaissances.

Cette incapacité d'accepter la formation des adultes en tant que discipline et domaine distinct provient d'une perception trop bornée du phénomène nommé "enseignement". Les préoccupations majeures des facultés de pédagogie sont la formation du personnel qualifié et l'avancement des connaissances des institutions traditionnelles d'enseignement dans la société. Alors la formation égale l'enseignement et les connaissance la formation.

La formation des adultes fonctionne dans le cadre des formes traditionnelles établies de l'enseignement ainsi qu'écartée d'elles. Par conséquent, il s'agit des activités pédagogiques dans un milieu social plus large. La conception de l'enseignement est plus vaste que celle de l'instruction scolaire. Il faut partir d'une base différente aussi. Alors, pour les cours d'adultes, l'enseignant a recours a des méthodes diverses et souvent méconnaissables à celui pour qui la perception de l'enseignement se borne aux formes établies. Il en résulte que l'enseignement aux adultes traite des termes et des concepts empruntés à la pédagogie mais formulés d'une autre façon pour qu'ils conviennent aux phénomènes rencontrés dans la formations des adultes. La formation professionnelle pour les responsables des cours d'adulte futurs aura nécessairement une portée plus vaste que l'instruction reçue par ceux qui seront à la tête des institutions académiques établies et sera intrinséquement différente de celle-ci. 
The development of an academic university program about adult education is no simple matter because it entails a radical departure from traditional thought about education. Thus, at the outset, it is necessary to establish the basic concepts about the field and discipline upon which graduate education will be built. But before these concepts can be identified it is necessary to analyze certain pre-suppositions.

\section{Pre-suppositions}

The existence of and justification for continuing education stems from the nature of human society ${ }^{6}$.

I. Human Society is a dynamic entity that constantly undergoes change leading to the advancement and improvement of the conditions of human existence.

II. A dynamic society requires members who are reasonably well adjusted and capable of making further adjustments to continuously changing conditions and circumstances.

III. This necessity for continuous adjustment requires continuous learning.

IV. The human animal is capable of learning continuously if provided with access to the learning required.

V. Because of the complexity of the human existence, a society must take special provisions to insure that the required learning is available.

Although these pre-suppositions are self-evident they are not universally recognized and accepted even by those involved in education. Thus, society has been slow in accepting the responsibility that insures the availability of opportunities for learning continuously. It was not until the early part of the nineteenth century that provisions were made for continuous education. At that time, too, came the awareness that education intended for adults must differ from that for children. This resulted in the first book about educating adults published in 1814 that coined the phrase adult education and laid the foundations for the discipline ${ }^{7}$.

Since then, continuing education for adults spread throughout the fabric of society and has become so pervasive that it is not recognized for what it is because it is not institutionalized. This pervasiveness creates problems for the discipline in that it is necessary to set parameters for its role. Adult education is concerned only with continuing education not with continuous learning and while there is a clear differentiation between these concepts, too many insist on including within the concerns of the discipline all adult learning whether or not education is involved ${ }^{8}$.

\section{Organizing Concepts}

The pre-suppositions identify the functional utility of adult education as a matter of vital concern. Simultaneously, they identify and clarify the basic concepts about it which help to organize graduate professional education. These organizing concepts are, in some ways, the criteria that set parameters for the content included in a program of study and help to identify the scope of relevant research.

Adult education is at one and the same time a field of social practice and a social science discipline. The nature and requirements of the field determine the form and content of the discipline while it, in turn, finds its subject for study in the field and educates the leadership for it. 
I. Adult education is a field of social practice in which adults are provided opportunities for systematic education to meet their persistent need to learn. Systematic education incorporates planned purposeful learning activities conducted under the continuing guidance of an educational agent who can influence the conditions for learning to increase the probability that the learning objectives will in fact be achieved. The field derives its ethos and ethic from the society in which it occurs. The field is identified as continuing education.

II. Adult education is a social science discipline. As such, it differs from some other disciplines and, to some extent, has its own unique characteristics ${ }^{9}$.

1. Adult education is a factual or descriptive discipline concerned both with the conditions influencing adult learning and with the factors affecting the provision of opportunities for systematic education for adults.

2. It is a normative discipline in that it is concerned with deliberate attempts to help adults develop in certain ways.

3. It is an eclectic discipline because it draws upon other disciplines for such knowledge as may be relevant to the education of adults ${ }^{10}$.

4. It is a practical discipline since its primary concern is the application of knowledge to the provision of opportunities for further education for adults.

Thus, the discipline of adult education concentrates on the discovery, interpretation, application, and diffusion of knowledge that will contribute to the achievement of more effective and efficient continuing education.

III. Continuing education permeates the total social milieu. Opportunities for systematic education are provided in many settings under the auspices of diverse agencies that have little in common other than their involvement with continuing education. In spite of such diversity in the field, there is a body of fundamental knowledge about educating adults that is common to every situation. To this common core may be added such specific knowledge as may be relevant to particular forms of continuing education $^{11}$.

IV. Although systematic educational activities for adults will usually produce learning, not all adult learning is of concern to the discipline of adult education.

This is not to say that the adult learning excluded here is without value or interest but since it is virtually an unidentifiable phenomenon it is unmanageable for either research or practice. Furthermore, some parameters must be established for the discipline and this seems the most logical point at which to set the boundaries. There are many in the field who are not in agreement on this point.

The field of continuing education requires an increasing number of individuals educated specifically to provide programs for adults ${ }^{12}$. This is emerging as a new profession related to but not identical with the teaching profession. The use of the term education in designating the field and the discipline has generated the assumption that education and training for this new profession is indistinguishable from the more familiar teaching education programs.

There is ample historical and experimental evidence available to indicate that the kind of knowledge and the learning experiences provided in teacher education are not appropriate for continuing education yet the myth of identity persists. This has been perpetuated in part by the generally accepted notion that all education is the same; in part by the 
complexity of the field that makes continuing education visible only in institutional forms; and in part by the failure to clarify the role and function of professional leadership in the field.

In the main, professional leadership in the field performs two main roles: ${ }^{13}$

\section{Instructional Role.}

This is the basic role of leadership and involves the design and management of specific educational activities for adults. Here the primary concern is with the selection and ordering of the learning tasks, the use of specific techniques and devices to facilitate learning, the continuing management of the learning activity, and the measurement of achievement.

\section{Administrative Role.}

In this role the leader is responsible for the use of institutional resources through determining program areas, clientele analysis, the selection of method, the management of operations, and the appraisal of the program achievements.

Formal institutions with large commitment to the education of adults usually employ personnel for one or another of these two roles and they are differentiated within the institutional structure. In many cases, however, the roles are not clearly distinguished so that a single individual may perform both roles interchangeably. This is the case with agriculture or home agents in the extension service. Because of this frequent melding of roles, the core program of professional education in adult education is necessary for everyone.

The basic knowledge that makes up the core content of the discipline is derived from a number of sources ${ }^{14}$. Some is appropriated without change from another discipline, some may be borrowed from elsewhere and re-formulated to suit adult education, and some knowledge is generated within the discipline itself. In the early development of the discipline most of the content originated in other disciplines but in later years the amount generated within adult education has increased remarkedly.

Because of the eclectic nature of the discipline it is desirable to formulate some criteria for the selection and adaptation of knowledge borrowed from elsewhere.

I. The knowledge helps to explain some phenomena encountered in the field or discipline.

II. It helps in the solution of practical problems encountered in the field.

III. It can be translated into operational principles that will contribute to greater efficiency and effectiveness in adult educational programming.

IV. It contributes to the development of essential attitudes, values, or skills important to the field.

V. It can be re-formulated so that it is applicable to adult education.

VI. It is derived solely from adult populations.

VII.It relates to systematic education for adults.

In the search for appropriate knowledge from other disciplines, these criteria can be particularly helpful in identifying segments of knowledge that might be otherwise overlooked. As an example of this neglect, very few universities include in their curriculum any consideration of the wealth of knowledge accumulated in the literature related to the acceptance and adoption of innovations yet this contains some of the most important 
information available. Similar neglect is evident with respect to literature on communication and social and applied anthropology.

The identification and selection of knowledge useful to adult education is a continuing process that requires periodic summary and codification. For this reason research reviews are a necessary adjunct in the development of the content of the discipline.

Over the years, the component knowledge at the core of the discipline has been catalogued and sorted into several categories that can be identified as follows: ${ }^{15}$

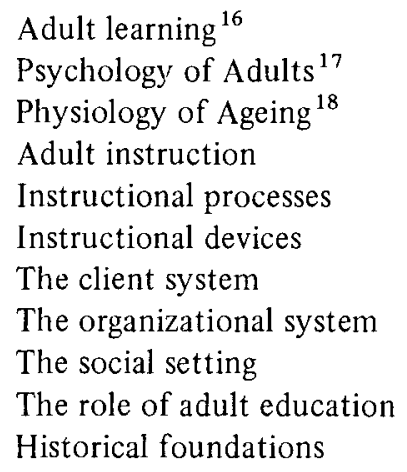

These categories define the primary areas of content and the major spheres for research. They provide a structure for course construction and for the identification of areas of specialization. To these core categories can be added such subsidiary units as may be indicated by the clientele in the field, but there is a danger of unnecessary and undesirable proliferation at this point.

Since adult education is an applied discipline some subsidiary divisions may be required within the structure of the basic core. At present there is a growing tendency to fragment the discipline into sub-units based on the providing institution, the potential clientele, or the content of the educational program. Such partitioning of the discipline stems from the complex and diffuse nature of the field rather than on the structure of knowledge in adult education. Thus, instead of adding a course in Adult Vocational Education because of presumed differences in learning or instruction on the basis of the content, we would be better advised to think in terms of the real learning problems encountered in vocational education. These learning problems fall into the psycho-motor domain but they are not associated solely with the learning of vocational skills. Psycho-motor learning is a distinct kind of learning that requires special consideration, particularly when adults are involved ${ }^{19}$. It is also encountered in learning an art of craft, in sports and games, or in musical performance. Thus there is no real difference in acquiring one kind of skill or another for what ever purpose or activity but there are real differences between the cognitive, affective, or psycho-motor domains of learning and instruction. A division of knowledge on this basis is logical and pragmatic because it has a more rational and extensive application to the kinds of educational problems encountered in the field.

A similar analysis can be made with respect to the organizational system or the client system. The administrative role involves essentially the same activities and responsibilities in every situation so that there is no real difference in function that is dictated by the form of the institution making it necessary to create sub-categories of knowledge by institution. A professionally educated adult educator can perform the administrative 
functions in a school system, university, or business with equal facility. Similarly, the functions exercised in the instructional role are not distinctly different in managing instruction for adult illiterates or continuing professional education, since the principles of adult learning and instruction are common to all adults in any learning situation.

To recapitulate, then, the courses constructed for professional education in adult education should be based on the nature and content of the discipline rather than on the characteristics of the field. This will emphasize commonalities and provide unity in the field.

In addition to information and skills, a professional education program in adult education must also include the development of attitudes and values related to the adult as a learner and the role of adult education. Such values are acquired more readily when they are present in the learning environment. Insofar as the normal constraints inherent in university graduate study will allow, the program should operate within a learning environment that is representative of the practices desired for the field. Thus, conditions should be established and fostered that will contribute to the growth of a professional esprit de corps and a common identity.

To establish such an environment it will be necessary to modify the traditional patterns of university study. The time honoured roles of student and teacher will be replaced by a learning group concept in which everyone shares the learning experience. In this way the program will demonstrate the application of knowledge to practice in such a way as to integrate theory and practice functionally.

In a good learning environment, the participants will acquire learning about adult education through the process of living as much as through courses. Therefore, the total experiences of the learner must become part of the curriculum and be planned as a total entity rather than solely as a series of courses.

The discovery of new knowledge and the establishment of new relationships among older fragments of knowledge is deeply embedded in the traditions of every academic discipline. In no other discipline, perhaps, is this more crucial than it is in adult education at this stage of development. In every discipline, knowledge begins with accumulated folk-wisdom derived from experience which leads to the formulation of principles and generalizations that govern practice. As a discipline matures these must be tested under controlled conditions so as to verify or reject them, in order to improve practice.

At the moment continuing education tends to operate more on the basis of folkwisdom than by certified fact, because it is difficult for people to abandon functional folk-principles even when they are know to be wrong. Folk-wisdom tells us that "you can't teach an old dog new tricks" and this shibboleth survives even among many in adult education in spite of the work of men such as Thorndike, Lorge, or Weschler which has long since rejected it. The lecture was long thought to be the best instructional technique and persists as of old even among adult educators although research informs us of its limitations.

Testing folk-wisdom is an important component of research in adult education but it is often inhibited by the state of research technology in the discipline. Of far greater importance, perhaps, is the development of instruments and techniques for the study of crucial problems in the field. A crucial matter, for example, is the assessment of the learning achieved in an activity yet adult education has developed too few instruments 
to that end ${ }^{20}$. Consequently, we have no sure way of determining the effectiveness of instruction.

In order to advance knowledge systematically, it is necessary for research to be cumulative rather than indiscriminately following the vagaries of the hour. To promote the systematic accumulation of knowledge for the discipline it is necessary to establish criteria for research.

I. The research deals exclusively with adults.

II. It is directly related to adult education.

III. It investigates real problems of concern to the field and/or the discipline.

IV. It contributes to an explanation of the phenomena with which adult education deals.

V. It tests the applicability to adult education of knowledge derived from other disciplines.

VI. It is directly related to previous research and contributes to the systematic accumulation of knowledge about educating adults.

VII. It contributes to the graduate professional education of leadership for the field.

Although a tremendous amount of knowledge about educating adults has been accumulated, there is little evidence of consistency and direction. Some effort must be made to develop a more systematic approach to research but it will be difficult to persuade individuals to accept that their enlightened self-interest should lead to unity rather than diversity.

\section{Coda}

After some twenty years of active involvement in professional education for adult educators it is possible to view the situation with some perspective. Although the quantitative growth has been phenomenal in both the field and the discipline, the qualitative progress is less encouraging. Too many university programs depreciate the importance of basing their content on substantive knowledge in preference to experiential learning. Too little history on the use of earlier writing is introduced so that students are historical illiterates even though history is directly relevant to the present. Too few of those involved in conducting graduate education think seriously and systematically about adult education so that there is no agreement on terminology, on the scope of programs, or on what is or is not relevant. As a result, there is little theory on which to build a discipline systematically.

\section{FOOTNOTES}

1. Cyril O. Houle, "The Emergence of Graduate Study in Adult Education," in Adult Education: Outlines of an Emerging Field of University Study. Edited by Gale Jensen, A.A. Liveright, and Wilbur C. Hallenbeck. (Washington, 1964.) pp. 69-83.

2. Cyril G. Houle and Peter Ford, "Doctorates in Adult Education," Adult Leadership, 23:74-75 (Sept. 1973).

3. Gary Dickinson and Dale Rusnell, "A Content Analysis of Adult Education." Adult Education, Adult Education, 21: 177-185 (Spring, 1971).

See also Huey B. Long and Stephen K. Agyekum, "Adult Education 1964-1973: Reflections of a Changing Discipline." Adult Education, 24: 99-120 (Winter, 1974). 
4. A.A. Liveright, "The Nature and Aims of Adult Education as a Field of Graduate Education," in Jensen, Liveright, and Hallen beck, op. cit., pp. 85-102.

5. Coolie Verner, "Definition of Terms," in: Jensen, Liveright and Hallenbeck, op. cit., pp. 27-39.

6. Coolie Verner, A Conceptual Scheme for the Identification and Classification of Processes for Adult Education. (Washington, 1962) p. 1.

7. Thomas Pole, $\boldsymbol{A}$ History of the Origin and Progress of Adult Schools ... (Bristol, 1814). See Pole's History of Adult Schools. A Reprint of the 1816 Edition with An Introduction and Bibliographical Notes by Coolie Verner. (Washington, 1967).

8. See: Coolie Verner, "Definition of Terms," op. cit., pp. 29-33.

9. Gale E. Jensen, "The Nature of Education as a Discipline." in Readings for Educational Researchers, edited by Gale E. Jensen. (Ann Arbor, 1960).

10. This characteristic was not included by Jensen but was added by the author here as an additional characteristic of adult education.

11. Malcolm S. Knowles, "The Field of Operations in Adult Education," in Jensen, Liveright, and Hallenbeck, op. cit., pp. 41-67.

12. Coolie Verner, Gary Dickinson, Walter Leirman, and Helen Niskala, The Preparation of Adult Educators. (Washington, 1970).

13. Coolie Verner and Alan Booth, Adult Education. (New York, 1964). pp. 34-38.

14. Gale E. Jensen, "How Adult Education Borrows and Reformulates Knowledge of Other Disciplines," in Jensen, Liveright, and Hallenbeck, op. cit., pp. 105-111.

15. See: Edmund de S. Brumner, et. al., An Overview of Adult Education Research. (Washington, 1959.)

16. As an example sec: Coolie Verner and Catherine V. Davison, Psychological Factors in Adult

Learning and Instruction. (Tallahassee, 1971).

17. See: Ledford J. Bischof, Adult Psychology. (New York, 1969).

18. See: Coolic Verner and Catherine V. Davison, Physiological Factors in Adult Learning and Instruction. (Tallahassee, 1971).

19. A.T. Welford, Fundamentals of Skill. (London, 1968).

20. For example see: R.P. Kropp and Coolie Verner, "An Attitude Scale Technique for Evaluating Meetings," Adult Education 7:212-215, (Summer, 1957). Although developed as an experiment, this scale is still used extensively and nothing has yet replaced it. 